\title{
PENERAPAN SISTEM INFORMASI ADMINISTRASI DI PONDOK PESANTREN ANAK DAN MADRASAH IBTIDAIYAH RAUDLATUL FALAH
}

\author{
Usman Sudibyo ${ }^{1}$, Ahmad Zainul Fanani ${ }^{2}$, Dedi Nurcipto ${ }^{3}$ \\ ${ }^{1,2}$ Program Studi Teknik Informatika Universitas Dian Nuswantoro Semarang \\ ${ }^{3}$ Program Studi Teknik Elektro Universitas Dian Nuswantoro Semarang \\ E-mail: ${ }^{1}$ usman.sudibyo@dsn.dinus.ac.id, ${ }^{2}$ ahmad.zainul.fanani@dsn.dinus.ac.id, \\ ${ }^{3}$ dedi.nurcipto@dsn.dinus.ac.id
}

\begin{abstract}
Abstrak
Program $\mathrm{I}_{\mathrm{b}} \mathrm{M}$ (Pengabdian masyarakat) yang akan dilakukan di Pondok Pesantren Anak Tahfidzul Qur'an (PPATQ) dan Madrasah Ibtidaiyah (MI) Raudlatul Falah Desa Bermi Kecamatan Gembong Kabupaten Pati adalah dengan penerapan sistem informasi manajemen administrasi yang berbasis teknologi informasi komputer untuk menunjang layanan kepada orang tua/wali santri agar lebih baik dan akuntabel. Perkembagan lembaga pendidikan PPATQ dan MI Raudlatul Falah yang semakin pesat dengan jumlah santri sekarang mencapai 350 anak menjadi potensi sekaligus menjadi tantangan untuk dapat memberikan layanan yang lebih baik kepada masyarakat secara umum dan orang tua/wali santri secara lebih khusus. Proses administrasi pencatatan yang dilakukan dengan cara manual atau hanya memberikan kuitansi kepada orang tua yang kemudian ada staf lain yang melakukan rekapitulasi membuat sering terjadi miskomunikasi dan kesalahan dalam proses pencatatan sehingga muncul komplain yang tidak baik. Perkembangan teknologi informasi komputer yang cukup pesat saat ini diharapkan dapat menjadi solusi untuk menyelesaikan permasalahan yang dihadapi oleh lembaga ini supaya lebih dipercya oleh masyarakat. Penerapan teknologi Sistem Informasi Manajemen Administrasi dengan koneksi jaringan lokal area diharapkan mampu mengintegrasikan administrasi di pesantren dan madrasah sehingga lebih mudah, cepat dan raoi dalam pengaturan serta pelaporannya. Sistem database yang dibangun dengan baik akan menjamin pencatatan yang akurat karena transaksi data terpusat dalam satu database. Implementasi aplikasi ini diharapkan semakin mempercepat dan memudahkan orang tua, pengurus maupun pengelola dalam bertransaksi.
\end{abstract}

Kata kunci-- PPATQ, MI, sistem informasi, layanan, akuntabel

\section{PENDAHULUAN}

Yayasan pondok pesantren anak-anak ini berdiri pada tanggal 1 juni 2009, yang dilatarbelakangi adanya keinginan masyarakat sekitar pada yayasan pendidikan yang mampu menampung dan memberikan pengajaran pada anak-anak mereka yang menginginkan anaknya menjadi hafidz. Hal ini senada seperti yang diungkapkan oleh Ustadz Nor Shokib,Ah, S. Pd.I. Dan dikatakan pula oleh seorang seniman terkenal mengatakan bahwa anak adalah harta yang berharga, begitu juga dalam puisi Khalil Gibran, anak merupakan putra putrid yang hidup yang rindu pada diri sendiri, jiwanya adalah penghuni rumah masa depan, kehidupannya terus berlangsung tiada henti. Hal ini dikatakan oleh KH. Ahmad Djaelani, AH, M. Si. Selaku ketua dewan pembina Yayasan Raudlatul Falah. 
Pada tahun pertama Pondok Pesantren hanya mendapatkan murid baru 6 orang santri, dan santri tersebut baru berasal dari daerah sekitarnya. Setahun kemudian santrinya bertambah menjadi 16 orang dan pada tahun berikutnya 2011 yaitu jumlah santrinya bertambah menjadi 50 orang, sampai tahun 2015 ini jumlah santri menjadi 300 orang yang berasal dari seluruh wilayah Jawa dan Luar Jawa. PPATQ berkembang sangat pesat selain dorongan dari lingkungan untuk mendirikan Pesantren, tempatnya juga sangat strategis karena jauh dari perkotaan sehingga memudahkan proses menghafal AlQur'an.

Seiring dengan semakin berkembangnya pesantren dan madrasah yang dikelola oleh Yayasan Raudlatul Falah, maka aktifitas pengelolaan administrasi semakin banyak dan kompleks membutuhkan penanganan yang baik dan terstruktur. Sebagai lembaga pendidikan yang melayani masyarakat luas dengan letar belakang yang berbeda dan wilayah yang jauh menuntut untuk dapat memberikan informasi yang cepat dan akurat sehingga memperikan kepuasan yang maksimal dimana dampaknya adalah citra pesantren dan madrasah yang semakin baik dan akuntabel.

Hasil observasi dan wawancara yang telah dilakukan dengan beberapa pihak baik orang tua/wali santri, pengurus, dan staf administrasi didapatkan beberapa keluhan diantaranya :

a. Orang tua/wali santri pada saat melakukan pembayaran administrasi baru diinformasikan apabila ada iuran tambahan sehingga merasa kurang persiapan, adanya keluhan kerang telitinya pencatatan sehingga ada beberapa administrasi yang belum terekap, proses penanganan pembayaran yang agak lama sehingga antrian cukup panjang.

b. Pengurus merasa kesulitan dan lama untuk mendapatkan laporan terkait dengan administrasi yang telah dilakukan oleh orang tua/wali santri kepada lembaga

Staf administrasi merasa melakukan pekerjaan ganda yaitu harus menerima proses administrasi dengan pencatatan kuitansi dan rekap ulang data kuitansi yang memungkinkan terjadi selisih karena terbatasnya SDM yang menguasai pengolahan data dengan computer dan perlengkapan computer itu sendiri sebagai media penyimpanan data.

\section{TINJAUAN PUSTAKA}

\section{Sistem Informasi}

Pada awal perkembangan komputerisasi informasi, komputer belum mempunyai program yang berjalan secara otomatis, melainkan hanya menjalankan komando yang dimasukkan secara manual ke dalam komputer. Setelah tahun 2000'an, sistem informasi manajemen mulai berkembang sebagai satu sistem yang terintegrasi pada berbagai induk perusahaan dan cabang-cabangnya.

Sistem tersebut kemudian dibentuk dalam sistem informasi berbasis komputer (Computer Based Information System). Hingga kini, sistem informasi berjalan secara terintegrasi dan berjalan secara otomatis. SIM sendiri mempunyai elemen-elemen fisik yang dibutuhkan untuk kelancaran sistem yang digunakan, yaitu perangkat keras komputer, perangkat lunak, yaitu perangkat lunak sistem umum, perangkat lunak terapan umum, serta program aplikasi. Selanjutnya, dalam SIM terdapat database dan prosedur 
pelaksanaan sistem manajemen perusahaan dan tentunya, petugas yang mengoperasikan semua sistem tersebut.

Fungsi utama diterapkannya sistem infomasi manajemen dalam suatu organisasi adalah sebagai berikut:

1. Mempermudah pihak manajemen untuk melakukan perencanaan, pengawasan, pengarahan dan pendelegasian kerja kepada semua departemen yang memiliki hubungan komando atau koordinasi dengannya.

2. Meningkatkan efisiensi dan efektifitas data yang tersaji akurat dan tepat waktu.

3. Meningkatkan produktifitas dan penghematan biaya dalam suatu organisasi.

4. Meningkatkan kualitas sumber daya manusia karena unit sistem kerja yang terkoordinir dan sistematis.

\section{SMS Gateway}

SMS (Short Message Service) bukan hal yang baru baru amat di dunia teknologi mobile, tetapi fungsionalitasnya sudah berakar dan tidak bisa lah dipisahkan dari kehidupan masyarakat kita. Walaupun teknologi seperti MMS, Blackberry Messenger, Nexian Messenger, chatting ataupun video call sedang berkembang. Cara bertukar informasi ala SMS dengan yang hanya menggunakan teks sederhana masih tetap menjadi pilihan utama. Tidak hanya terbatas hanya untuk sarana komunikas pengganti percakapan lisan diantara dua orang, SMS saat ini juga digunakan sebagai alat untuk vooting, kuis, lelang, banking, order barang, promosi, undangan, payment dan lain sebagainya.

SMS bisa jadi populer tentunya karena punya kelebihan tersendiri yang terletak pada kesederhanaannya, sehingga mudah untuk diaplikasikan. Semua ponsel memiliki fitur SMS, tidak perduli apakah ponselnya dukung 3G, touch screen, dual SIM card, atau hanya ponsel berlayar 1 baris seperti kalkulator. SMS juga tetap dapat dikirim walaupun ponsel si penerima sedang tidak aktif dalam limit waktu, karena SMS itu punya yang namanya validity period. Penyampaian SMS juga biasanya lebih cepat jika dibandingkan dengan mengirimkan lewat messenger. Tidak juga bergantung pada sinyal GPRS yang kadang tidak stabil. Biaya yang saat ini juga relatif murah juga menjadi salah satu alasan kenapa SMS digunakan secara luas. SMS Gateway merupakan sebuah sistem aplikasi yang digunakan untuk mengirim dan atau menerima SMS, dan biasanya digunakan pada aplikasi bisnis, baik untuk kepentingan broadcast promosi, servis informasi terhadap pengguna, penyebaran content produk / jasa dan lain lain.

Fitur yang ada dalam SMS gateway bisa kita modifikasi sesuai dengan kebutuhan.berikut adalah beberapa fitur yang umum dikembangkan dalam aplikasi SMS Gateway :

a. Auto Reply

b. Pengiriman massal / broadcast message

c. Pengiriman terjadwal

Untuk membuat sebuah SMS gateway, hal yang memegang peranan penting dalam pengiriman SMS adalah SMSC (Short Message Service Center). yang merupakan jaringan telepon selular yang menangani pengiriman SMS.

\section{METODE PELAKSANAAN}

Kegiatan pengabdian kepada masyarakat ini akan dilaksanakan di 2 mitra yaitu Pondok Psantren Anak Tahfidzul Qur'an (PPATQ) dan Madrasah Ibtidaiyah (MI) Raudlatul Falah Desa Bermi Kecamatan Gembong Kabupaten Pati, dengan jangka waktu 
pelaksanaan secara keseluruhan adalah 10 (sepuluh) bulan. Rangkaian kegiatan yang akan dilakukan sesuai hasil kesepakatan dan rapat bersama mitra baik mulai perencanaan, pengembangan system informasi, instalasi jaringan dan aplikasi, pelatihan operasional penggunaan aplikasi, pendampingan dan perbaikan aplikasi backup data, pendampingan implementasi system. Kegiatan pengabdian masyarakat ini direncanakan seperti ditunjukkan pada Gambar 1

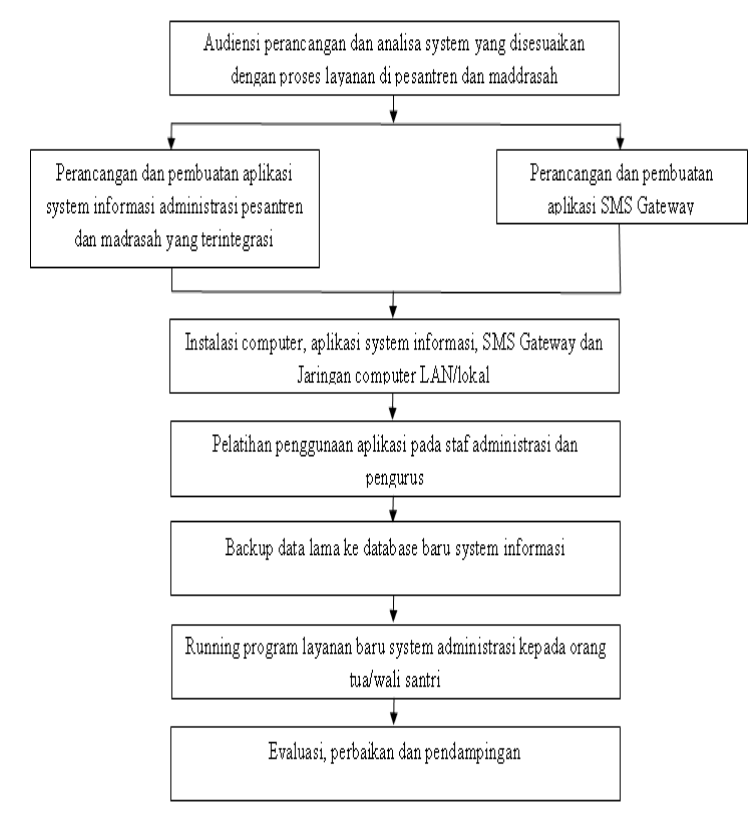

Gambar 1. Alur Proses Kegiatan Pengabdian

Secara lebih detail mekanisme penyusunan dan penerapan aplikasi berbasis system informasi yang akan diterapkan pada mitra seperti ditunjukkan pada Gambar 2 


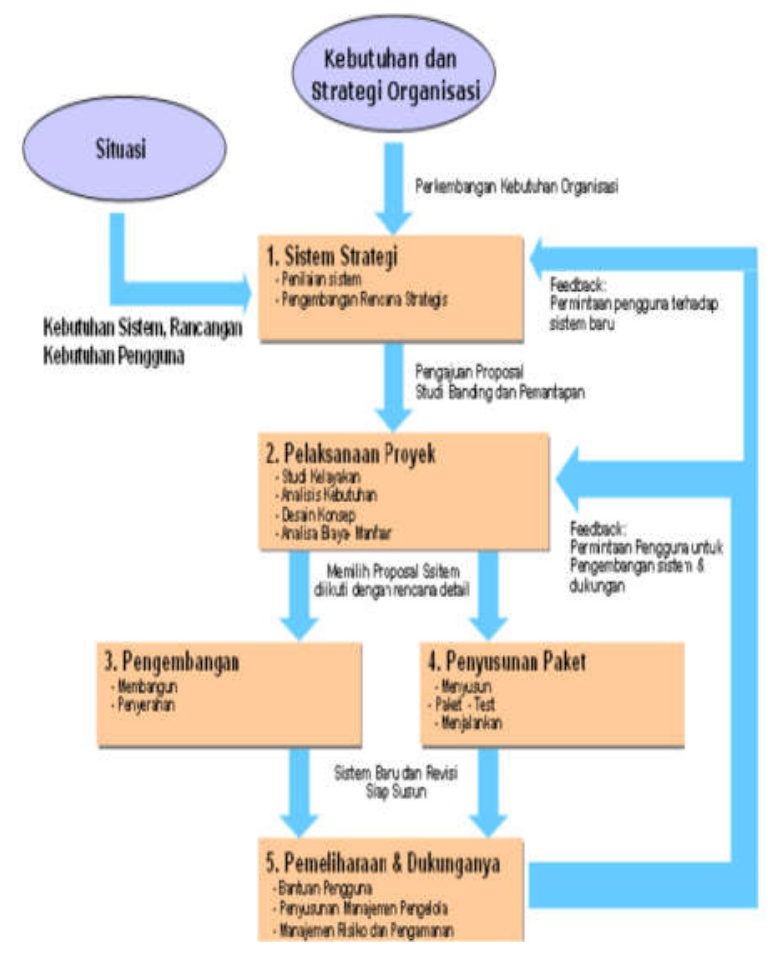

Gambar 2. Konsep pengembangan dan penerapan aplikasi SIM

\section{HASIL DAN PEMBAHASAN}

\section{Tahap persiapan}

Pada tahapan ini dilakukan proses analisis proses bisnis atau aktifitas yang dilakukan oleh bagian administrasi pondok pesantren dan MI Raudlatul Falah untuk mendapatkan gambaran proses sistem dan alur informasi yang akan dijadikan dasar dalam pengembangan sistem informasi nantinya.

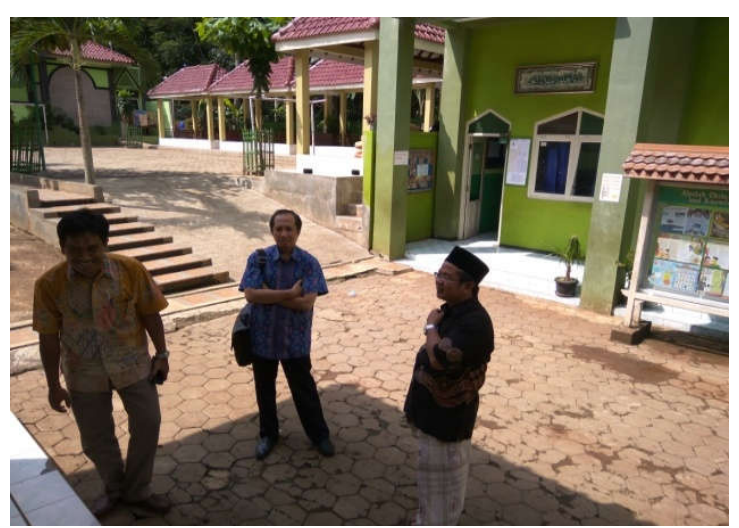

Gambar 3. Diskusi dengan pengasuh pondok pesantren

2. Tahapan pengembangan sistem informasi 
ABDIMASKU, Vol. 1, No. 1, Januari $2018: 1-9$

Pada tahapan ini dilakukan pengkodean untuk membangun sebuah aplikasi sistem informasi administrasi yang mudah digunakan sesuai dengan kebutuhan yang didentifikasi pada tahapan sebelumnya.

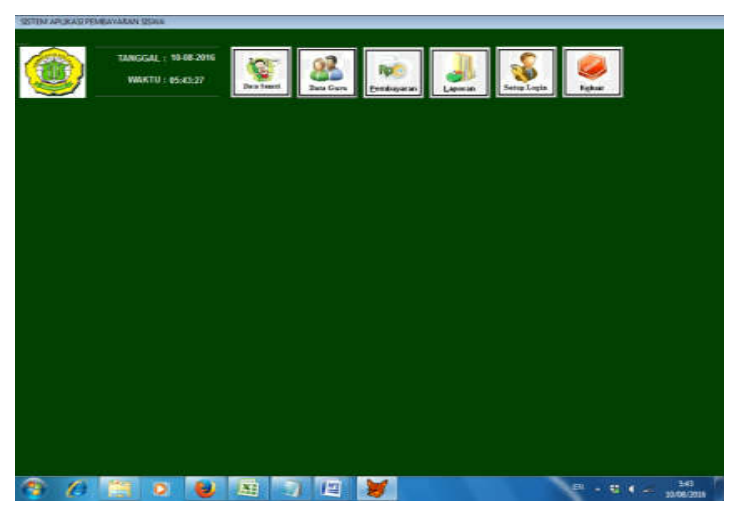

Gambar 4. Menu utama aplikasi

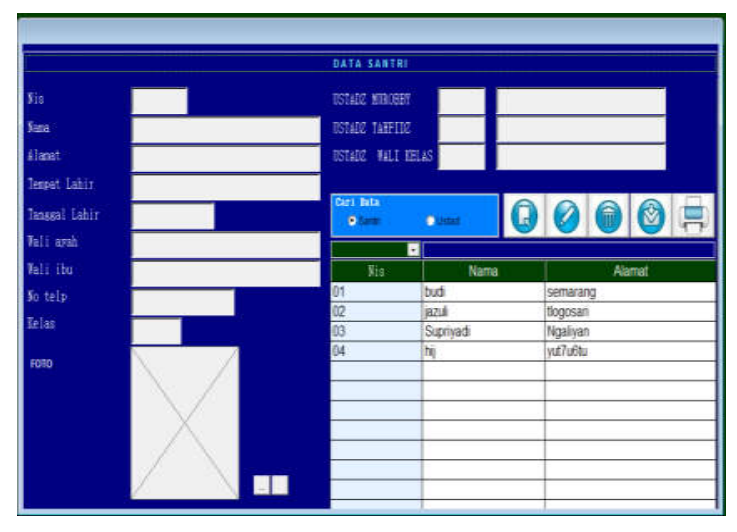

Gambar 5. Form input data siswa/santri

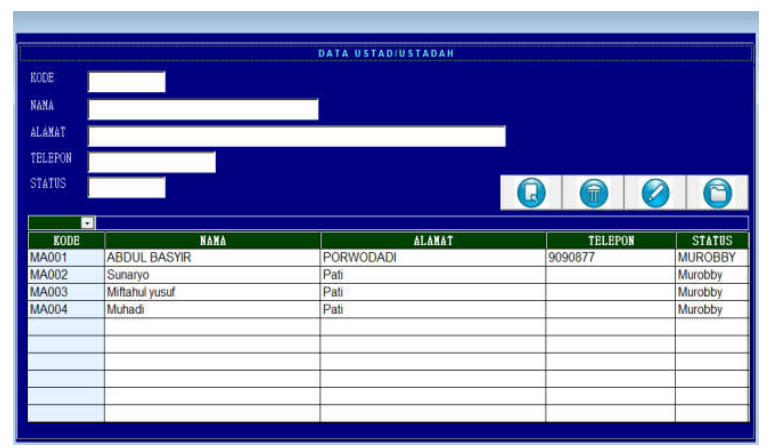

Gambar 6. Form input data guru/ustadz 


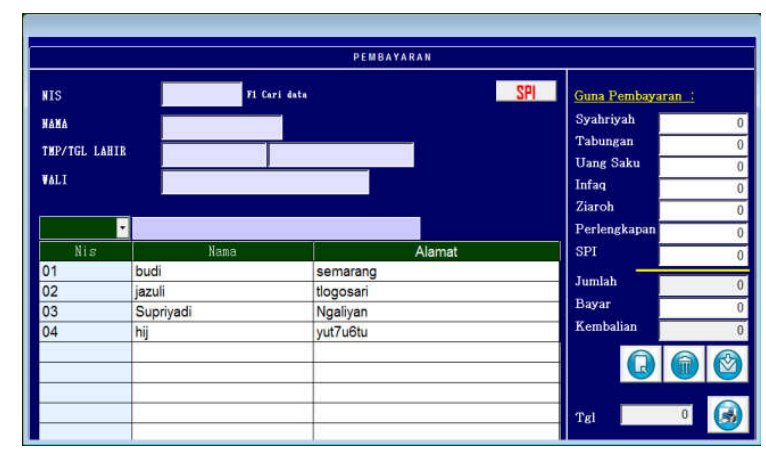

Gambar 7. form input transaksi administrasi

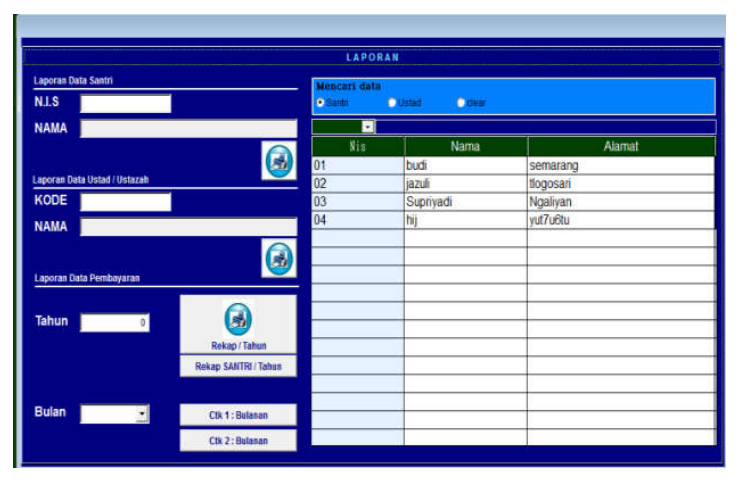

Gambar 8. Form cetak laporan

Pada tahapan berikutnya setelah diimplementasikannya aplikasi Sistem informasi administrasi pesantren maka untuk memberikan informasi yang lebih cepat maka dirancanglah suatu media yang dapat memberikan informasi dari database kepada wali santri. SMS gateway merupakan piihan media yang dapat digunakan untuk mengirim informasi yang cepat dan akurat sesuai dengan database pesantren kepada seluruh wali santri. Teknologi aplikasi SMS gateway yang telah diimplementasikan seperti ditunjukkan pada Gambar 9 dan 10. 


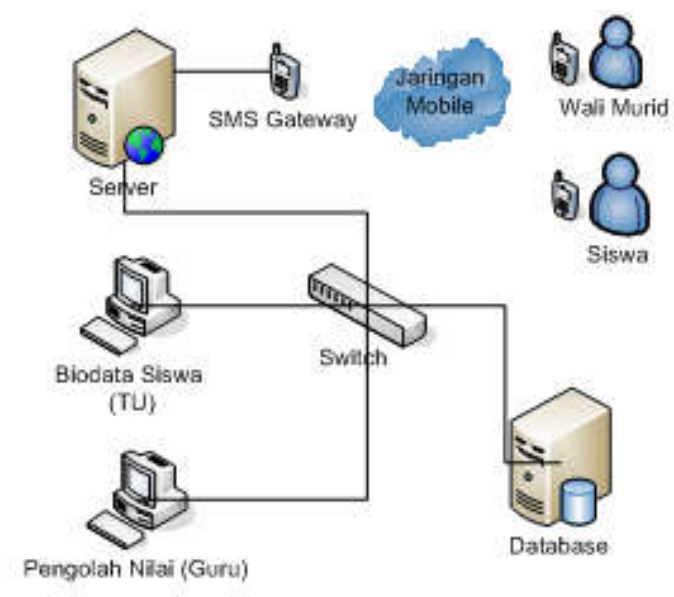

Gambar 9. Skema SMS Gateway

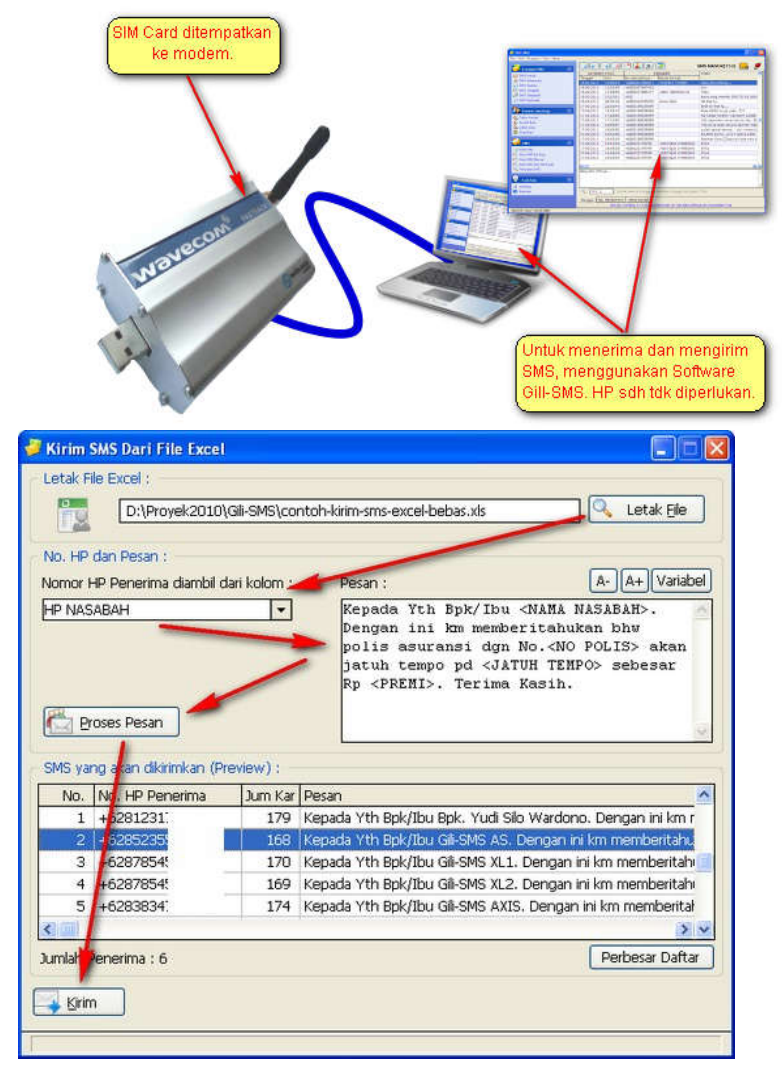

Gambar 10. Aplikasi hardware dan software SMS Gateway

Dari hasil implementasi yang dilakukan akan diukur proses pelayanan yang diberikan oleh staf administrasi dengan memanfaatkan aplikasi yang telah diberikan. Rata -rata waktu pelayanan yang diberikan kepada wali santri pada saat melakukan aktifitas administrasi pembayaran menjadi lebih cepat dari yang awalnya 8 menit menjadi 5 menit. Sedangkan tingkat kepuasan wali santri terhadap layanan yang diberikan semakin meningkat dangan rata-rata merasa "Sangat Puas" dengan aplikasi yang sudah diterapkan oleh pesantren. 


\section{KESIMPULAN}

Dari pelaksanaan kegiatan program pengabdian Iptek bagi Masyarakat (IbM) ini dapat disimpulkan:

1. Meningkatnya waktu pelayanan yang diberikan oleh staf administrasi

Berkurangnya panjang antrian pembayaran wali santri pada saat proses administrasi

\section{DAFTAR PUSTAKA}

Hambali, Erliza dkk. (2007), Teknologi Bioenergi. Jakarta: Agro Media.

Hamni, Arinal. (2008). Rancang Bangun dan Analisa Tekno Ekonomi Alat Biogas dari Kotoran Ternak Skala Rumah Tangga, Jurusan Teknik Mesin Universitas Lampung.

Junus, M (1987). Teknik Membuat danMemanfaatkan Unit Gas bio.Fakultas Peternakan Universitas

Brawijaya. Gadjah Mada University Press: Yogyakarta.

Setiawan, Ade Iwan (1996), Memanfaatkan Kotoran Ternak, Jakarta: Penebar Swadaya.

Sudarno, Nano dkk. (2010). Biogas, Mengolah Limbah menjadi Berkah, Bandung: Yayasan Pendidikan

Lingkungan Kesehatan dan Kesejahteraan.

Wahyono, E.H. dkk (2009). Panduan Kegiatan Lapangan PNPM LMP.WCS-Indonesia Program, Bogor 